\title{
Impact of the insulation materials' features on the determination of optimum insulation thickness
}

\author{
Jérôme Barrau $\cdot$ Manel Ibanez $\cdot$ Ferran Badia
}

Received: 18 June 2013/Accepted: 7 February 2014/Published online: 4 April 2014

(c) The Author(s) 2014. This article is published with open access at Springerlink.com

\begin{abstract}
The optimum thickness of the building envelope insulation materials depends on a large number of parameters. But the optimum thickness is calculated considering only economic arguments. In this paper, life-cycle assessment of the materials used in the building, and specifically the insulation ones, are included in the process to calculate the optimum insulation thickness from both environmental and energetic points of views. Within this frame, the large influence of the parameters associated with the manufacturing of the materials on the determination of the optimum thickness has been demonstrated: For all the studied cases, the insulation thickness depends in a large way on the unitary economic, energetic and environmental costs. The biggest differences in optimum thicknesses between two different insulation materials correspond to the highest differences in the unitary costs, for all the optimization points of views. The study also demonstrates that increasing values of the characteristic parameters of the manufacturing phase, which depend on the nature of the insulation materials, imply a decrease of the impact of the calculation settings, associated with the use phase of the building.
\end{abstract}

5th International Congress on Energy and Environmental Engineering and Management (CIIEM).

J. Barrau $(\bowtie) \cdot$ M. Ibanez · F. Badia

Applied Physics Section of the Environmental Sciences

Department, University of Lleida, 25001 Lleida, Spain

e-mail: jerome.barrau@udl.cat

M. Ibanez

e-mail: m.ibanez@macs.udl.cat

F. Badia

e-mail: fbadia@macs.udl.cat
Keywords Insulation materials - Optimum thickness Life-cycle assessment · Energy savings · Environmental issues

\section{Introduction}

As buildings are responsible for around $27 \%$ of the final end use of energy in the EU-27 [1], a very high interest exists in reducing their energy consumption. Building insulation is one of the best options to reach this goal [2-5]. The determination of the optimum thickness of insulation materials in the building envelope is one of the main objectives of this scientific area [6]. This thickness depends on a large number of parameters. Scientific studies are primarily focused on analyzing the effect of the climatic parameters [7-12], orientation [13, 14], thermal mass [15], fuels $[9,11,16,17]$, and other parameters $[10,18,19]$. These studies only consider the economical point of view.

The planet is facing huge environmental and energetic problems and the EU directives on the energy performance of buildings are oriented to reduce primary energy consumption and environmental impact ( $\mathrm{CO}_{2}$ emissions) [20]. Some authors incorporate the savings in energy consumption or greenhouses emissions, but considering only the use phase of the building [21, 22]. In the majority of scientific works, the optimum thickness is calculated considering only the economic point of view. Nevertheless, some papers include the life-cycle cost analysis (LCCA) from the energetic point of view and very few ones include the lifecycle assessment (LCA) of the materials used in the building, and specifically of the insulation materials [23, 24].

The calculation procedure for the economic, energetic and environmental optimum insulation thicknesses is very 
similar: For the energetic and environmental assessments, the initial investment, used for the economic LCCA, is substituted by the embodied energy and the global warming potential of the greenhouse gases associated with the manufacture of the insulation material, respectively.

Within this framework, Ostermeyer et al. [25] adapted without major changes the simplified method presented by Petersdorff et al. [26], originally designed to calculate the optimum insulation thickness from the economic point of view, to consider environmental parameters. The authors showed that the insulation thicknesses obtained from the environmental optimization point of view, taking into account the life cycle of the materials, are much higher than the ones obtained from the economic assessment. Their study was limited to mineral wool insulation material.

In this context, the present study has been developed with the following objectives: (1) quantify how the optimum thickness values, based on economic, energetic and environmental points of views, vary as a function of the insulation materials and (2) identify the relevant parameters, focusing on the ones related to the fabrication process of the insulation materials that determines the optimum insulation thicknesses.

\section{Methodology}

A simplified analytical procedure is used to compare the optimum insulation thickness obtained for the economic, energetic and environmental points of views. These values correspond to the insulation thicknesses that provide the highest economic, energetic and environmental savings, respectively, along the whole life cycle of the building (50 years in this work). For each optimization point of view, the calculation procedure takes into account, on the one hand, the initial investments at the construction phase of the building and its insulation materials and, on the other hand, the savings provided by its implementation, during the use phase of the building. The obtained values are theoretical values and so do not take into account the feasibility of its implementation.
These values are calculated in ten scenarios (Table 1) with four insulation materials: mineral wool (MW), cork (C), polyurethane (PUR) and wood fiber (WF). The properties of these materials are presented in Table 2 .

The calculation settings' impact on the optimum insulation thicknesses has been checked by including variations in the main parameters considered in the calculation procedure.

The studied environmental impact $\left(\mathrm{CO}_{2 \mathrm{u}}\right)$ is the global warming potential associated with the material along its whole life cycle, expressed through the equivalent carbon dioxide parameter (in $\mathrm{kg} \mathrm{CO}_{2}$ eq. $/ \mathrm{m}^{3}$ ). The energetic parameter $\left(E_{\mathrm{u}}\right)$ is expressed through the total primary energy used by the materials along their whole life cycle (in $\mathrm{MJ} / \mathrm{m}^{3}$ ).

The hypotheses used for the model are the following:

- House dimensions, $9 \times 6 \times 2.5 \mathrm{~m}^{3}$.

- Floor and ceiling, adiabatic (dwelling located vertically between two equal housing characteristics and occupation).

- Optimum insulation thickness determined by the building heating demand.

- Ventilation losses included.

- Solar gains and internal heat sources not included.

- Efficiency of $90 \%$ for both biomass and gas space heating systems.

Table 2 Insulation material data applied [27, 28]

\begin{tabular}{|c|c|c|c|c|}
\hline \multirow{2}{*}{$\begin{array}{l}\text { Insulation } \\
\text { materials }\end{array}$} & \multicolumn{3}{|c|}{ Fabrication and installation costs } & \multirow{2}{*}{$\begin{array}{l}\text { Thermal } \\
\text { conductivity } \\
\lambda(\mathrm{W} / \mathrm{m} \mathrm{K})\end{array}$} \\
\hline & $\begin{array}{l}€_{\mathrm{u}} \\
\left(€ / \mathrm{m}^{3}\right)\end{array}$ & $\begin{array}{l}E_{\mathrm{u}} \\
\left(\mathrm{MJ} / \mathrm{m}^{3}\right)\end{array}$ & $\begin{array}{l}\mathrm{CO}_{2 \mathrm{u}} \\
\left(\mathrm{kg} \mathrm{CO}_{2} \text { eq. } / \mathrm{m}^{3}\right)\end{array}$ & \\
\hline $\begin{array}{l}\text { Mineral wool } \\
\text { (MW) }\end{array}$ & 77 & 900 & 30 & 0.04 \\
\hline $\begin{array}{l}\text { Polyurethane } \\
\text { (PUR) }\end{array}$ & 216 & 4,320 & 380 & 0.023 \\
\hline $\begin{array}{l}\text { Wood fiber } \\
\text { (WF) }\end{array}$ & 211 & 2,124 & 78 & 0.04 \\
\hline Cork (C) & 192 & 234 & 26 & 0.045 \\
\hline
\end{tabular}

Table 1 Calculation settings

The calculation settings for $\mathrm{CF} 2-\mathrm{CF} 10$ are the same as $\mathrm{CF} 1$, except when a value is presented in the table

\begin{tabular}{|c|c|c|c|c|c|c|c|c|c|c|c|}
\hline \multirow[t]{2}{*}{ Parameter } & \multirow[t]{2}{*}{ Unit } & \multirow{2}{*}{$\begin{array}{l}\text { Base } \\
\text { CF1 }\end{array}$} & \multicolumn{9}{|c|}{ Variations } \\
\hline & & & $\mathrm{CF} 2$ & CF3 & CF4 & CF5 & CF6 & CF7 & CF8 & CF9 & CF10 \\
\hline$U_{\text {ow }}$ & $\mathrm{W} / \mathrm{m}^{2} \mathrm{~K}$ & 1.5 & 3 & 0.5 & & & & & & & \\
\hline ren & $\mathrm{ren} / \mathrm{h}$ & 1 & & & & 3 & & & & & \\
\hline HDD & ${ }^{\circ} \mathrm{C} /$ day & 3,199 & & & 2,083 & & & & & & 1,128 \\
\hline Windows & $\%$ & 25 & & & & & 50 & & 50 & & \\
\hline U Windows & $\mathrm{W} / \mathrm{m}^{2} \mathrm{~K}$ & 3.5 & & & & & & 1.8 & 1.8 & & \\
\hline Fuel & $(-)$ & Gas & & & & & & & & Biom. & \\
\hline
\end{tabular}


- The global warming potential of the greenhouse gases emissions during the fabrication process of the insulation materials is expressed through the carbon dioxide emissions, as the databases do not offer the total greenhouse gases mixture for all the considered insulation materials.

Solar gains, internal loads and other building characteristics have intentionally not been included in the calculation procedure to check exclusively the impact of the insulation materials' characteristics on the optimum insulation thicknesses. This hypothesis implies an overestimation of the optimum insulation thicknesses. So the results may not be evaluated quantitatively by themselves, but in comparison with values obtained for other insulation materials.

On the one hand, the annual costs associated with the use phase of the building are calculated. For this, it is necessary to assess the annual costs in terms of energy during this stage, which is the annual energy consumption $\left(E_{\mathrm{USE}}\right)$ :
$\mathrm{VR}=\frac{\operatorname{ren} \times V}{3,600}$

The thermal transmittance of the complete opaque wall ( $\left.U_{\text {cow }}\right)$ is given by its thermal resistance $\left(R_{\text {cow }}\right)$ :

$U_{\text {cow }}=\frac{1}{R_{\text {cow }}}$

with

$R_{\mathrm{cow}}=R_{\mathrm{ow}}+R_{\mathrm{ins}}$

where $R_{\text {ow }}$ is the thermal resistance of the opaque walls without the insulation layer, and $R_{\mathrm{ins}}$ is the thermal resistance of the insulation layer that depends on its thickness $(x)$ and its thermal conductivity $(\lambda)$ :

$R_{\text {ins }}=\frac{x}{\lambda}$

So, the annual cost in terms of energy during the use phase $\left(E_{\mathrm{USE}}\right)$ is

$E_{\mathrm{USE}}=\frac{\left[\left(\frac{1}{R_{\mathrm{ow}}+\frac{\mathrm{x}}{x}}\right) \times A_{\mathrm{cow}}+U_{\mathrm{w}} \times A_{w}+\mathrm{VR} \times \rho_{\text {air }} \times \mathrm{Cp}_{\text {air }}\right] \times\left(\mathrm{HDD} \times \mathrm{f}_{\mathrm{u}} \times \mathrm{i} \times 86,400\right)}{\eta}$

$$
E_{\mathrm{USE}}=\frac{q}{\eta}
$$

where $\eta$ is the efficiency of the heating system and $q$ is the annual heat losses, which take into account the losses through the complete opaque walls $\left(q_{\text {cow }}\right)$ and the windows $\left(q_{\mathrm{w}}\right)$, and the ones due to ventilation $\left(q_{\mathrm{vent}}\right)$.

$q=q_{\mathrm{cow}}+q_{\mathrm{w}}+q_{\mathrm{vent}}$

with

$q_{\text {cow }}=U_{\text {cow }} \times A_{\text {cow }} \times \mathrm{HDD} \times f_{\mathrm{u}} \times i \times 86,400$

$q_{\mathrm{w}}=U_{\mathrm{w}} \times A_{\mathrm{w}} \times \mathrm{HDD} \times f_{\mathrm{u}} \times i \times 86,400$

and

$q_{\text {vent }}=\mathrm{VR} \times \rho_{\text {air }} \times \mathrm{Cp}_{\text {air }} \times \mathrm{HDD} \times f_{\mathrm{u}} \times i \times 86,400$

$f_{\mathrm{u}}$ and $i$ are, respectively, the use and intermittence coefficients. The first is related to the number of heating days per month and the second to the number of hours of heating per day. As the building considered in this paper is a house, $f_{\mathrm{u}}=1$ and $i=0.85$.

The ventilation rate VR (in $\mathrm{m}^{3} / \mathrm{s}$ ) is given by the air renewal rate ren (in $\mathrm{ren} / \mathrm{h}$ ) and the volume $V$ of the building:
From the economic and environmental points of view, the annual costs during the use phase $\left(€_{\mathrm{USE}}\right.$ and $\mathrm{CO}_{2}$ USE $)$ are $€_{\mathrm{USE}}=E_{\mathrm{USE}} \times C_{\mathrm{f}}$

and

$\mathrm{CO}_{2}$ USE $=E_{\mathrm{USE}} \times K_{\mathrm{f}}$

where $C_{\mathrm{f}}$ and $K_{\mathrm{f}}$ are, respectively, the conversion factors from energetic to economic cost and from energetic to environmental costs (Table 3).

On the other hand, the energetic, economic and environmental annual costs associated with the fabrication and the installation of the insulation materials $\left(E_{\mathrm{yi}}, €_{\mathrm{yi}}\right.$ and $\mathrm{CO}_{2 \mathrm{yi}}$, respectively), are calculated as follows:

$E_{y_{i}}=\frac{E_{y_{0}}}{N}$

Table 3 Fuel data [29-32]

\begin{tabular}{lll}
\hline Fuels & $K_{\mathrm{f}}\left(\mathrm{kg} \mathrm{CO}_{2} / \mathrm{MJ}\right)$ & $C_{\mathrm{f}}(€ / \mathrm{MJ})$ \\
\hline Gas & $5.7 \times 10^{-2}$ & $1.58 \times 10^{-2}$ \\
Biomass & 0 & $0.94 \times 10^{-2}$
\end{tabular}

Lowest heating values (LHV) of fuels are included in $C_{\mathrm{f}}$ and $K_{\mathrm{f}}$ 
Fig. 1 Optimum insulation thickness. Economic $\left(x_{€}\right)$, energetic $\left(x_{\mathrm{E}}\right)$ and environmental points of views $\left(x_{\mathrm{CO}_{2}}\right)$. Material: cork

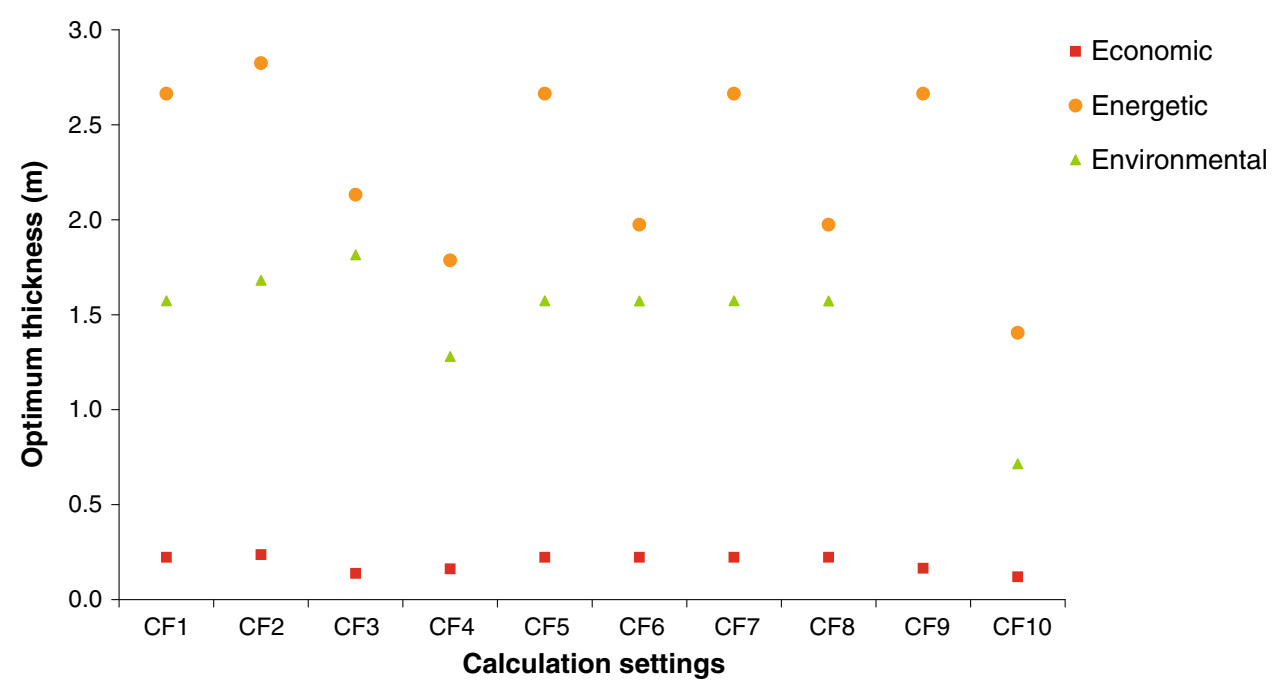

$\mathrm{CO}_{2 y_{i}}=\frac{\mathrm{CO}_{2 y_{0}}}{N}$

to make the annual balance from the economic, energetic and environmental objectives.

In the economic analysis, the interests were not included in the calculation to apply the same procedure to all the assessments:

$E_{\mathrm{a}}=E_{\mathrm{USE}}+E_{y_{i}}$

$€_{\mathrm{a}}=€_{\mathrm{USE}}+€_{y_{i}}$

$\mathrm{CO}_{2 \mathrm{a}}=\mathrm{CO}_{2 \text { USE }}+\mathrm{CO}_{2 y_{i}}$ installation at year 0 from the
environmental points of views:

$E_{y_{0}}=E_{\mathrm{u}} \times V_{\mathrm{ins}}$

$€_{y_{0}}=€_{\mathrm{u}} \times V_{\mathrm{ins}}$

$\mathrm{CO}_{2 y_{0}}=\mathrm{CO}_{2 \mathrm{u}} \times V_{\text {ins }}$

The unitary costs of the insulation materials for the energetic $\left(E_{\mathrm{u}}\right)$, economic $\left(€_{\mathrm{u}}\right)$ and environmental $\left(\mathrm{CO}_{2 \mathrm{u}}\right)$ optimizations are given in Table 2. The volume of the insulation material $\left(V_{\text {ins }}\right)$ depends on its thickness $(x)$ and the area of the opaque walls $\left(A_{\text {ow }}\right)$ :

$V_{\text {ins }}=x \times A_{\text {ow }}$

So the energetic, economic and environmental annual costs associated with the fabrication and the installation of the insulation materials $\left(E_{y_{i}}, €_{y_{i}}\right.$ and $\mathrm{CO}_{2 y_{i}}$, respectively) can be expressed as follows:

$E_{y_{i}}=\frac{E_{\mathrm{u}} \times x \times A_{\mathrm{ow}}}{N}$

$€_{y_{i}}=\frac{€_{\mathrm{u}} \times x \times A_{\mathrm{ow}}}{N}$

$\mathrm{CO}_{2 y_{i}}=\frac{\mathrm{CO}_{2 \mathrm{u}} \times x \times A_{\mathrm{ow}}}{N}$

In Eqs. (10)-(12) and (20)-(22), the insulation thickness $(x)$ is the only unknown value and so we can combine the parameters of the use phase and the ones of the LCA phase
The minimum value of annual costs, relative to the energetic $\left(E_{\mathrm{a}}\right)$, economic $\left(€_{\mathrm{a}}\right)$ and environmental $\left(\mathrm{CO}_{2 \mathrm{a}}\right)$ points of view, correspond to the optimum insulation thicknesses for each of these factors ( $x_{\mathrm{E}}, x_{€}$ and $x_{\mathrm{CO}_{2}}$, respectively).

\section{Results and discussion}

Optimum thickness dependence on material

As commented in "Introduction", many studies calculate the optimum insulation thicknesses from the economic point of view. Figure 1 shows that, for a given insulation material, the optimum thickness depends noticeably on the optimization point of view used for its calculation.

It is observed that the insulation thickness can be, for the cork, more than 15 times higher in the energetic optimization than in the economic one. The rate between the optimum thicknesses calculated through the environmental and the economical assessments is also higher than 13 .

Moreover, the impact of the insulation material on the calculated thickness is also studied. Figure $2 \mathrm{a}-\mathrm{c}$ presents the optimum insulation thicknesses obtained for the ten calculation scenarios and for the four studied materials through, respectively, the economic, energetic and 
Fig. 2 Impact of the insulation material on the calculated thickness. a Optimum insulation thickness; economic assessment. b Optimum insulation thickness; energetic assessment. c Optimum insulation thickness; environmental assessment
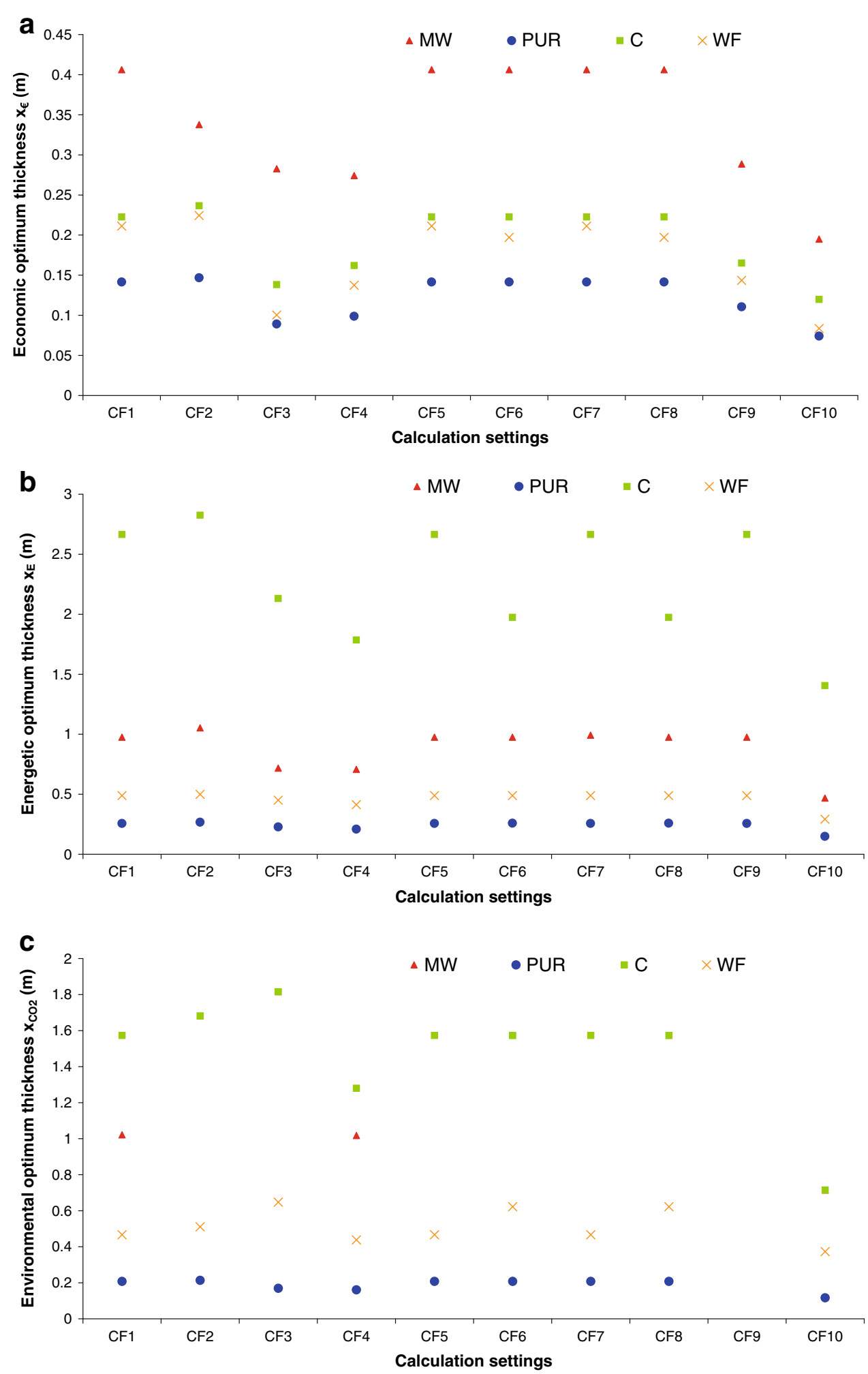

environmental points of view. For the environmental results (Fig. 2c), the low $\mathrm{CO}_{2}$ emissions associated with the manufacture of mineral wool do not allow reaching an optimum thickness. The same occurs with calculation setting CF9, where the use of biomass eliminates the $\mathrm{CO}_{2}$ emissions during the use phase of the building.

We can observe that the order of the optimum thickness varies depending on the optimization point of view. For 
Table 4 Rates between optimum thicknesses for different materials calculated through the economic, energetic and environmental points of views

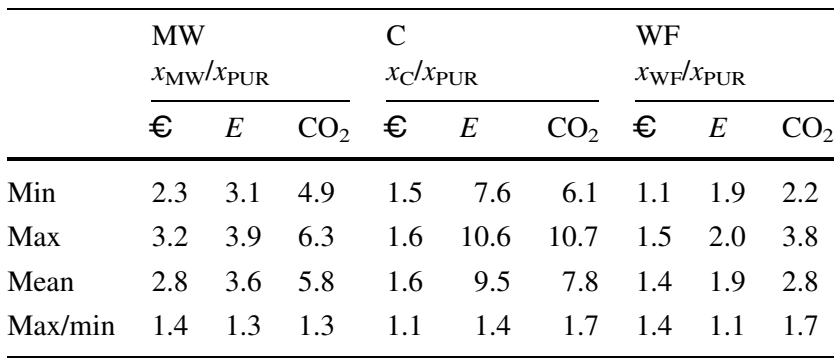

each one, the general trend is similar for the four insulation materials studied. Nevertheless, the dispersion of the results in the different calculation settings, for a given optimization point of view, is higher when the insulation thicknesses are higher. This demonstrates that, in such cases, the impact of the calculation settings, and therefore of the use phase of the building, is higher.

From the economic point of view, the rate between the highest thicknesses (mineral wool) and the lowest (polyurethane) is close to 3 (Table 4).

For the energetic and environmental optimizations, the highest thicknesses are obtained for cork, followed by mineral wool, wood fiber and finally polyurethane. The maximum rate between the highest and the lowest thicknesses are 10.6 and 10.7 for, respectively, the energetic and environmental optimization assessments.

Relevant parameters for the determination of the optimum insulation thickness

Optimum thicknesses based on economic, environmental and energetic points of view show important differences depending on the insulation material. The influence of the unitary costs of the insulation materials is represented in Fig. 3a-c.

For the three optimization points of views and the three calculation settings represented, the optimum thicknesses decrease when the unitary costs increase. For the energetic and environmental points of views, we can observe an asymptotic trend, related to the fact that the energy savings have also, as a function of the insulation thickness, an asymptotic trend. As the economic unitary costs of the insulation materials are not so closely dependent on their performance, there is not a clear trend in the case of the economic optimization point of view.
Also, for all the optimization points of views, the difference between the optimum thicknesses obtained in the three calculation settings reduces as the unitary costs grow. This is due to the fact that the characteristics for each calculation setting (related to the use phase of the building) have a larger specific weight in the optimum thickness determination when, in the materials manufacturing stage, the unitary costs are lower.

The mean rate, based on all the scenarios studied, between optimum thicknesses for cork, mineral wool and wood fiber with respect to the ones of polyurethane has been calculated for the three optimization points of views. Figure 4 represents these values as a function of the economic, energetic or environmental unitary cost rates for the same materials.

The large impact of the manufacturing phase of the insulation materials is demonstrated. Indeed, as the difference between the unitary costs increases (low cost rates), the difference between the optimum thicknesses also increases. But the direct relation between the optimum thickness rate and the cost rates does not have a large dependence on the optimization point of view. In fact, trends obtained for the three views are closer. The difference between the trend line and the real values comes from the thermal properties of the insulation materials.

\section{Conclusions}

A simplified method has been used for quantifying the impact of the insulation material characteristics of the manufacture process on the economic, energetic and environmental optimum insulation thicknesses. The large influence of the parameters associated with the manufacturing phase of the insulation materials on the determination of the optimum thickness has been clearly shown. For all the optimization points of views studied, the insulation thickness depends in a large way on the unitary costs associated to the fabrication of the materials. The biggest differences in thickness between two different isolation materials correspond to the highest difference in the unitary costs. As a consequence, the differences for energetic or environmental optimization assessments are larger than for the economic one. The study also demonstrates that increasing values of the characteristic parameters of the manufacturing phase, which depend on the nature of the 
Fig. 3 Important differences of the optimum thicknesses.

a Optimum insulation thickness as a function of costs in the manufacturing stage; economic assessment. b Optimum insulation thickness as a function of costs in the manufacturing stage; energetic assessment. c Optimum insulation thickness as a function of costs in the manufacturing stage; environmental assessment

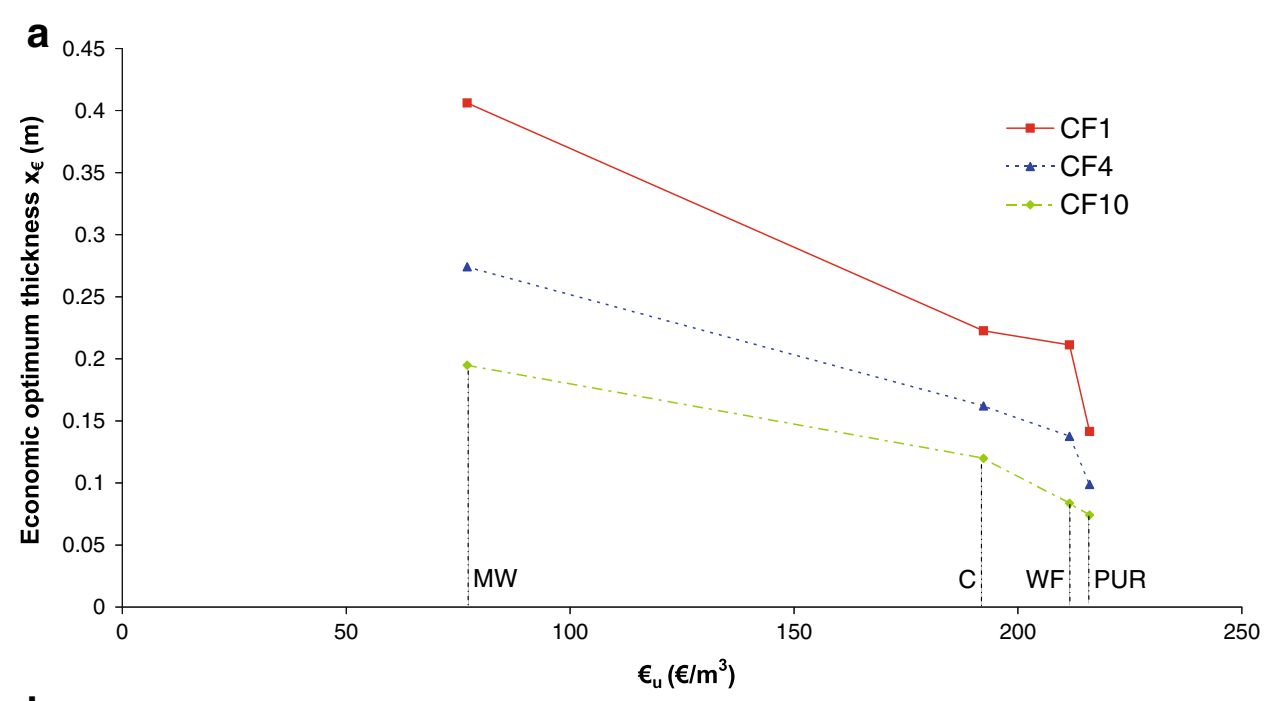

b
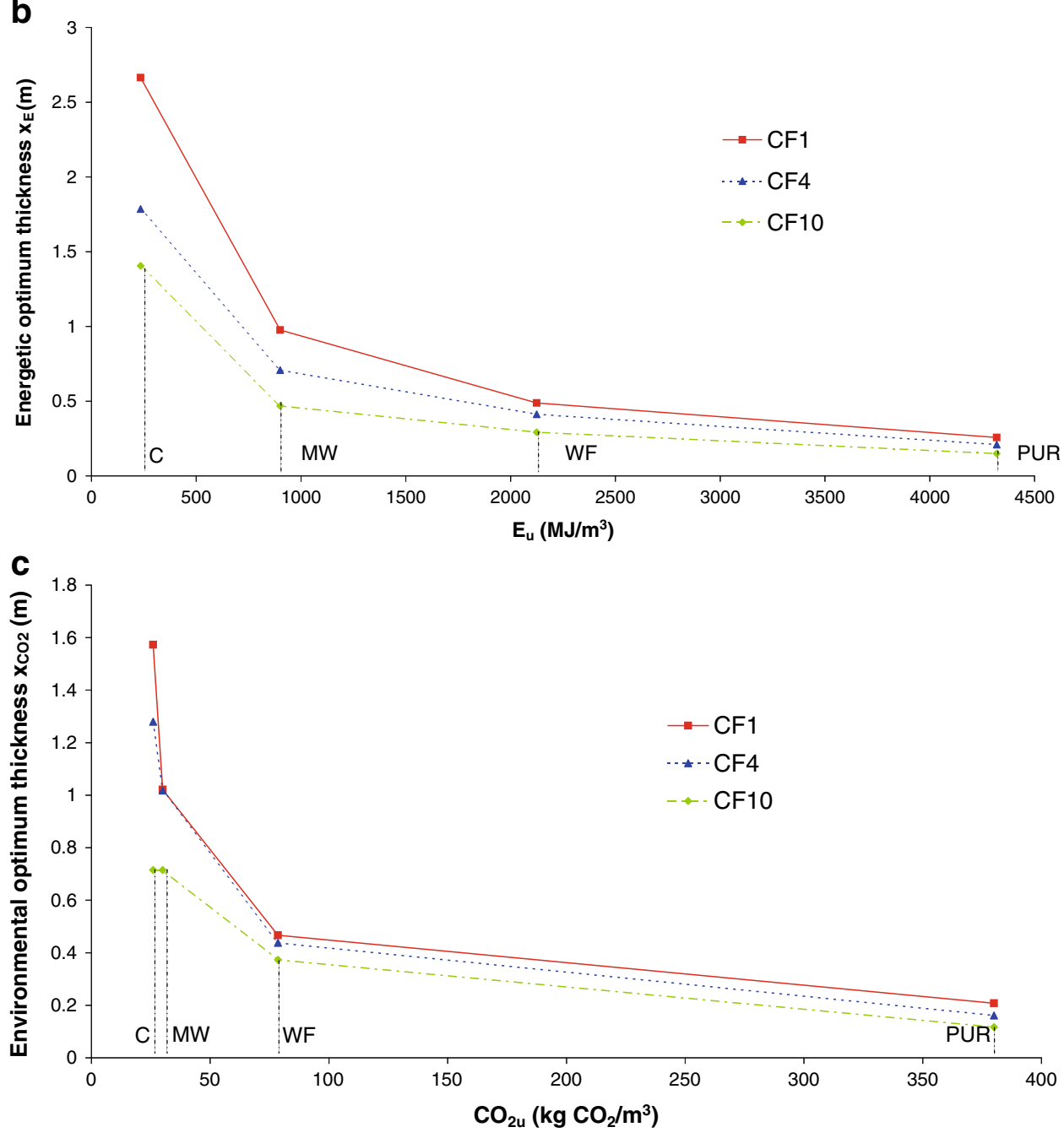
Fig. 4 Optimum thickness rates versus unitary cost rates (cork, mineral wool, wood fiber)/ polyurethane

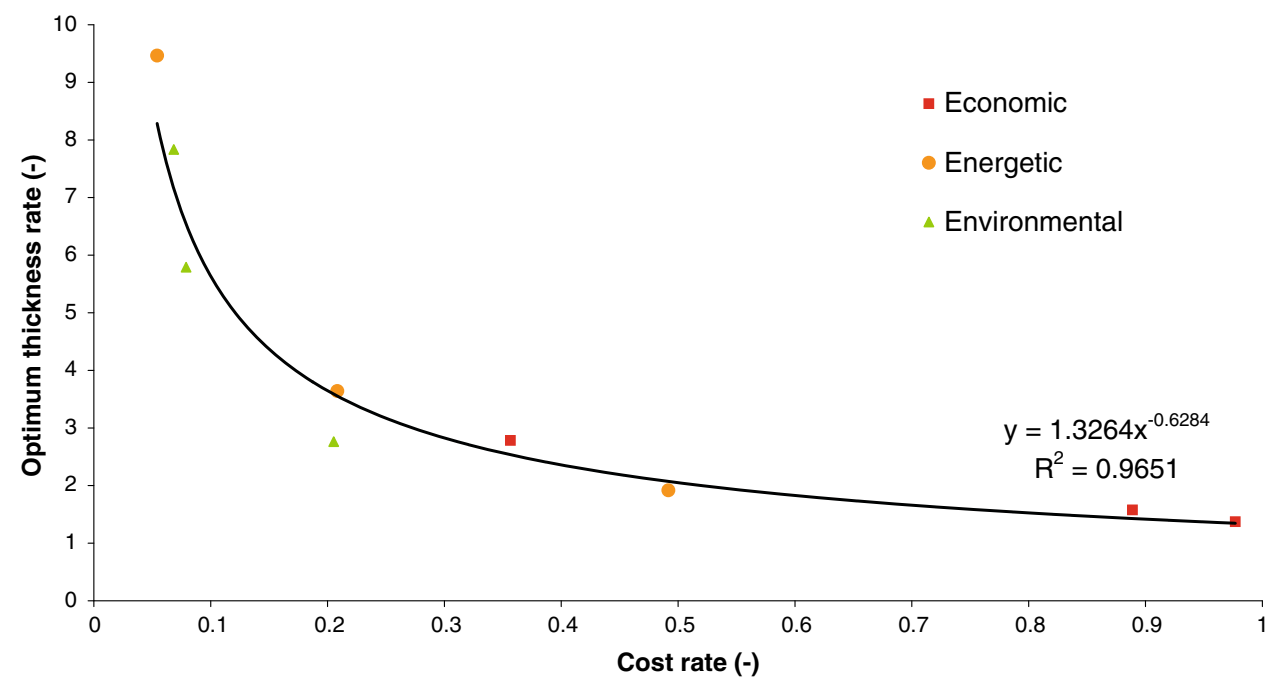

insulation materials, imply a decrease of the impact of the calculation settings, associated with the use phase of the building.

Acknowledgments The authors acknowledge the solar energy group of the University of Lleidafor its support.

Conflict of interest The authors declare that they have no competing interests.

Authors' contributions JB carried out the analytic assessment. MI and FB participated in the analysis of the results. All authors read and approved the final manuscript.

Open Access This article is distributed under the terms of the Creative Commons Attribution License which permits any use, distribution, and reproduction in any medium, provided the original author(s) and the source are credited.

\section{References}

1. Database of consumption of energy of the European Union (2012) Eurostat. European Commission. http://epp.eurostat.ec.europa.eu/ statistics_explained/index.php/Consumption_of_energy. Accessed 20 Feb 2013

2. Wang Y, Huang Z, Heng L (2007) Cost-effectiveness assessment of insulated exterior walls of residential buildings in cold climate. Int J Project Manag 25:143-149

3. Ghrab-Morcos, N.: CHEOPS: a simplified tool for thermal assessment of Mediterranean residential buildings in hot and cold seasons. Energy Build. 37, 651-662 (2005)

4. Mohsen, M.S., Akash, B.A.: Some prospects of energy savings in buildings. Energy Convers Manag 42, 1307-1315 (2001)

5. Al-Homoud, M.S.: Performance characteristics and practical applications of common building thermal insulation materials. Build Environ 40, 353-366 (2005)

6. Kaynakli, O.: A review of the economical and optimum thermal insulation thickness for building applications. Renew Sustain Energy Rev 16, 415-425 (2012)
7. Bolattürk, A.: Optimum insulation thicknesses for building walls with respect to cooling and heating degree-hours in the warmest zone of Turkey. Build Environ 43, 1055-1064 (2008)

8. Yu, J., Yang, C., Tian, L., Liao, D.: A study on optimum insulation thicknesses of external walls in hot summer and cold winter zone of China. Appl Energy 86, 2520-2529 (2009)

9. Bolattürk, A.: Determination of optimum insulation thickness for building walls with respect to various fuels and climate zones in Turkey. Appl Therm Eng 26, 1301-1309 (2006)

10. Özkan, D.B., Onan, C.: Optimization of insulation thickness for different glazing areas in buildings for various climatic regions in Turkey. Appl Energy 88, 1331-1342 (2011)

11. Çomaklı, K., Yüksel, B.: Optimum insulation thickness of external walls for energy saving. Appl Therm Eng 23, 473-479 (2003)

12. Al-Khawaja, M.J.: Determination and selecting the optimum thickness of insulation for buildings in hot countries by accounting for solar radiation. Appl Therm Eng 24, 2601-2610 (2004)

13. Ucar, A., Balo, F.: Determination of the energy savings and the optimum insulation thickness in the four different insulated exterior walls. Renew Energy 35, 88-94 (2010)

14. Ozel, M.: Effect of wall orientation on the optimum insulation thickness by using a dynamic method. Appl Energy 88, 2429-2435 (2011)

15. Al-Sanea, S.A., Zedan, M.F.: Improving thermal performance of building walls by optimizing insulation layer distribution and thickness for same thermal mass. Appl Energy 88, 3113-3124 (2011)

16. Al-Sanea, S.A., Zedan, M.F., Al-Ajlan, S.A.: Effect of electricity tariff on the optimum insulation-thickness in building walls as determined by a dynamic heat-transfer model. Appl Energy 82, 313-330 (2005)

17. Dombayc1, Ö.A., Gölcü, M., Pancar, Y.: Optimization of insulation thickness for external walls using different energy-sources. Appl Energy 83, 921-928 (2006)

18. Ozel, M.: Thermal performance and optimum insulation thickness of building walls with different structure materials. Appl Therm Eng 31, 3854-3863 (2011)

19. Mahlia, T.M.I., Taufiq, B.N., Ismail, B.N., Masjuki, H.H.: Correlation between thermal conductivity and the thickness of 
selected insulation materials for building wall. Energy Build 39, 182-187 (2007)

20. (2003) Directive 2002/91/EC of the European Parliament and of the Council of 16 December 2002 on the Energy Performance of Buildings. Off J Eur Union L 001:65-71

21. Çomaklı, K., Yüksel, B.: Environmental impact of thermal insulation thickness in buildings. Appl Therm Eng 24, 933-940 (2004)

22. Dombaycı, Ö.A.: The environmental impact of optimum insulation thickness for external walls of buildings. Build Environ 42, 3855-3859 (2007)

23. Ardente, F., Beccali, M., Cellura, M., Mistretta, M.: Building energy performance: a LCA case study of kenaf-fibres insulation board. Energy Build 40, 1-10 (2008)

24. Anastaselos, D., Giama, E., Papadopoulos, A.M.: An assessment tool for the energy, economic and environmental evaluation of thermal insulation solutions. Energy Build. 41, 1165-1171 (2009)

25. Ostermeyer Y, De Schryver A, Wallbaum H (2011) Optimal insulation thicknesses according to different indicators for Germany. In: Towards life cycle sustainability management, life cycle management (LCM), Berlin, Germany. http://www. lcm2011.org/papers.html. Accessed 16 Jan 2013

26. Petersdorff C, Boermans T, Harnisch J (2002) The contribution of mineral wool and other thermal insulation materials to energy saving and climate protection in Europe. Report by ECOFYS. http://www.eurima.org/. Accessed 16 Jan 2013

27. (2012) Online available BEDEC database, Spain, Catalonia Institute of Construction Technology. (ITeC). http://www.itec.es/ nouBedec.e. Accessed 16 Jan 2013

28. CSTB (2012) INIES, French database for environmental and health characteristics of construction products. http://www.inies. fr. Accessed 16 Jan 2013

29. (2007) Technical Guide for consumption accounting. Institute for Energy Diversification and Saving (IDAE). http://www.minetur. gob.es/energia/. Accessed 16 Jan 2013

30. (2007) Technical guide on procedure for regular inspection of energy efficiency for boilers. Institute for Energy Diversification and Saving (IDAE). http://www.idae.es/. Accessed 17 Jan 2013

31. Ahorro y Eficiencia Energética en Invernaderos (2008) Instituto para la Diversificación de la energía (IDAE). http://www.idae.es/. Accessed 17 Jan 2013

32. Boletín Oficial del Estado (BOE). $\mathrm{N}^{\circ}$ 314, Section I, p. 89609. 31/12/2012. Ministerio de Industria Energía y Turismo, Tarifa de Último Recurso del Gas Natural. http://www.boe.es/. Accessed 17 Jan 2013 